\title{
A framework for the successful implementation of food traceability systems in China
}

Yanqing Duan, University of Bedfordshire Business School, University of Bedfordshire

Luton, United Kingdom

Meiyin Miao, School of Engineering, China Agricultural University, Beijing, People's

Republic of China

Ruimei Wang, School of Economics and Management, China Agricultural University, Beijing, People's Republic of China

Zetian Fu, School of Engineering, China Agricultural University, Beijing, People's

Republic of China

Mark Xu, Portsmouth Business School, University of Portsmouth, Portsmouth, United

Kingdom

Corresponding Author:

Professor Yanqing Duan,

University of Bedfordshire Business School,

Vicarage Street, Luton,

Bedfordshire, LU1 3JU, UK.

Email: Yanqing.Duan@beds.ac.uk

Tel: +44 (0)1582 743134 .

RUNNING HEAD: Food Traceability Systems 


\title{
A Framework for the Successful Implementation of Food Traceability Systems in China
}

\begin{abstract}
Implementation of food traceability systems in China faces many challenges due to the scale, diversity and complexity of China's food supply chains. This study aims to identify critical success factors specific to the implementation of traceability systems in China. Twenty-seven critical success factors were identified in the literature. Interviews with managers at four food enterprises in a pre-study helped identify success criteria and five additional critical success factors. These critical success factors were tested through a survey of managers in eighty-three food companies. This study identifies six dimensions for critical success factors: laws, regulations and standards; government support; consumer knowledge and support; effective management and communication; top management and vendor support; and information and system quality.
\end{abstract}

Keywords: Traceability Systems, Critical Success Factors, Information Systems Success, Chinese Food Enterprises 


\section{A Framework for the Successful Implementation of Food Traceability Systems in China}

\section{Introduction}

Traceability in the food sector is particularly important, because an effective traceability system can promptly identify, single out and remove unsafe food products from the market (Liao et al., 2011; Liu et al., 2013). However, the successful implementation of food traceability systems in China faces many challenges due to the scale, diversity and complexity of the food supply chains. This is a pressing problem because although food safety laws with tough penalties has been enacted in China problems have continued to occur with disturbing frequency (Jia \& Jukes, 2013; Mao et al., 2015).

Traceability systems use information and communication technologies (ICTs) for product identification, information capture, analysis, storage and transmission, as well as integration of overall systems (Aung \& Chang, 2014). They require the identification of all the physical entities and locations from which the product originates, i.e. where it is processed, packaged, and stocked, including every agent in the supply chain (Regattieri et al., 2007). New conceptual and technical advances such as the Internet of Things, DNA barcoding, chemometrics modeling and the like can further advance the development of food traceability systems (Badia-Melis et al., 2015).

A literature review by Karlsen, et al. (2013) reveals that there is no common understanding of the definitions and principles of traceability, nor is there a sound common theoretical framework for implementing food traceability systems. They therefore call for a common theoretical framework, so as to enable better understanding of why implementations of food traceability succeed or fail. Accordingly, this study seeks to establish a critical success factors ${ }^{1}$ (CSF) framework for the implementation of

${ }^{1}$ Critical success factors, as originally defined by Rockart (1979), are "the limited number of areas in which results, if they are satisfactory, will ensure successful competitive performance for the organization. They are the few key areas where 'things must go right' for the business to flourish" and "areas of activity that should receive 
traceability systems based on empirical evidence collected in China.

The rest of the discussion is organized as follows. First the existing research on food traceability systems and their critical success factors is discussed. Then pre-study interviews and results are discussed. Thereafter the survey and data analysis are discussed. Lastly, the concluding comments are offered.

\section{Food Traceability Systems}

Traceability systems for the entire food supply chain ought to be capable of identifying product attributes, process attributes, environmental conditions and participant node attributes effectively, and recording the information of food logistics through each node in the central database. This develops the capability of top-down tracking of raw materials, processing, packaging, storage, transportation, and marketing in the food supply chain, and capability of bottom up tracing when food safety problems occur to promptly identify problem areas and take necessary actions (Lin \& Zhou, 2005). Researchers have developed and applied a number of traceability systems to different products, such as genetically modified food quality traceability system (Miraglia, 2004), agricultural products supply chain quality traceability information storage system (Cimino \& Lazzerini, 2005), aquatic product traceability system (Caswell, 2006), meat quality traceability system (McMeekin \& Baranyi, 2006) and perishable food quality traceability system framework (Regattieri et al., 2007). RFID technology has enhanced food supply chain traceability (e.g. Chen et al., 2008; Kelepouris, 2007; Peets et al., 2009).

However, a recent review of food traceability trends and advances by BadiaMelis et al. (2015) suggests that current traceability systems in practice do not capture, link and share the food traceability data accurately and effectively. Notwithstanding the vital role of traceability systems for ensuring food quality and safety, they are often perceived as barriers by food enterprises because of high implementation costs and shortage of skilled personnel (Bosona \& Gebresenbet, 2013). Sioen (Sioen et al., 2007)

constant and careful attention from management" (p. 85). 
suggest that globalization of trade and the lack of international standards and harmonization of laws have contributed to the difficulties of effective traceability system implementation, e.g. identifying the country of origin and history of seafood products is difficult. A pan-European study shows that incorrect country of origin labeling (COOL) of seafood products is common, as opposed to being an exception, e.g. almost $90 \%$ of the seafood samples collected from Belgian retail outlets were labeled incorrectly (Jooken \& Lauryssen, 2006). This is similar to the findings of another Norwegian study that almost $40 \%$ of the considered fish products could not be traced back to the fishing vessel or the fish farmer (Karlsen \& Senneset, 2006).

Other implementation issues for traceability systems, as reported from recent literature, are summarized below:

- Lack of adequate investment (Pizzuti \& Mirabelli, 2015);

- Lack of motivation of food enterprises because of perceived low cost-benefit ratio (Bosona \& Gebresenbet, 2013; Chryssochoidis et al., 2009; Karlsen et al., 2011; Storøy et al., 2013);

- Lack of relevant skills and knowledge for effective implementation of food traceability systems (Bosona \& Gebresenbet, 2013; Jia \& Jukes, 2013; Pizzuti \& Mirabelli, 2015);

- Lack of adequate laws and regulations, and regulatory enforcement (Jia \& Jukes, 2013; Pizzuti \& Mirabelli, 2015; Storøy et al., 2013);

- Lack of adequate standardization and effective collaboration among food traceability systems (Bosona \& Gebresenbet, 2013; Storøy et al., 2013);

- Concerns about data security and sharing sensitive information by food enterprises (Storøy et al., 2013).

- Lack of awareness among food supply chain partners (Bosona \& Gebresenbet, 2013).

- Traceability is associated with inherent uncertainty (Bollen et al., 2007).

Food traceability systems have a number of unique characteristics as compared to other types of enterprise systems. They are chain-based systems, as food supply chains are complex and dynamic due to the nature of food products and the requirements for 
food safety. Food traceability systems also involve a very wide range of stakeholders from both public and private sectors (Howard et al., 2012; Pizzuti \& Mirabelli, 2015). This generates complex interactions at multiple levels that have a bearing on the individual, the enterprise and the society.

European Union (EU) countries have taken the lead in enforcing implementation of food traceability systems. The United States, Japan and other developed countries have regulations that actively promote the implementation of food traceability systems (Pizzuti \& Mirabelli, 2015). The Chinese Government has also enacted a series food safety laws and regulations (Jia \& Jukes, 2013). An early traceability system for vegetables was implemented in Shandong Province in 2004, as a demonstration project by National Barcode Project Promotion Office. Thereafter, Beijing, Shanghai and other large cities have implemented various types of traceability systems covering vegetable, meat, fish and seafood. The majority of these systems have been implemented with the support of the government in collaboration with agriculture and food supply chain enterprises. In 2015, “The People's Republic of China Food Safety Law” was amended (Government, 2015) to increase penalties and address risk evaluation mechanisms, accountability of local government and enterprises, consumer rights, and traceability and food recall.

Traceability systems in China are characterized by a) strong government push and financial support; b) prioritization of a few key food supply chains, i.e. meat, vegetables and fruit, aquatic products, c) implementation by relatively large food companies in provincial cities, and d) low awareness and engagement from end consumers. A number of studies focusing on Chinese traceability systems reported problems, which are listed as below:

- The complexity involved in system integration because of scale (Zen, 2005);

- The difficulties in collecting a large amount of information because of low educational level of employees and lack of a sense of responsibility among managers and employees (Chen, 2008; Li, 2006; Mao et al., 2015; Xu et al., 2008; Zhang et al., 2007);

- Challenges in making traceability information collected useful to company 
managers and consumers (Zhang et al., 2007);

- High cost of implementing traceability systems, due to the lack of affordable traceability equipment in China. Imported technologies and equipment for traceability implementation lead to increased costs for food enterprises (Chen, 2008; Li, 2006; Xu et al., 2008; Zhu, 2008);

- Lack of effective national law enforcement and governmental audit programs specific to food traceability implementation (Chen, 2008; D'Amico et al., 2014; Jia \& Jukes, 2013; Li, 2006; Xu et al., 2008; Zhu, 2008).

These studies highlight a number of issues related to traceability system implementation including system integration, user motivation, organizational costs and benefits and legislation enforcement, but none of the studies have attempted to identify CSF for traceability systems implementation.

\section{Critical Success Factors for Traceability Systems}

\section{Relevant theoretical models}

Food traceability systems are essentially Information Systems (IS) that enable food traceability but with distinctive characteristics associated with the national and global food chain. Traceability systems implementation can be seen as the adoption of innovative information systems in enterprises operating in a complex food supply chain environment; hence the models on technology adoption provide useful guidance here. Effective implementation of traceability systems is also a matter of IS success, thus the models of IS success and CSF are also relevant.

Technology-Organization-Environment (TOE) framework is one of the widely recognized and used frameworks in technology adoption and diffusion research. The TOE model identifies three contextual factors that influence the implementation of a technological innovation: technology, organization, and environmental (Tornatzky et al., 1990). Technological context refers to both the internal and external technologies relevant to the firm - current practices and equipment internal to the firm as well as the set of available technologies external to the firm. The organizational context refers to the structure, resources and processes of the organization (Morgan \& Finnegan, 2007), 
which support the acceptance of an innovation. Environmental context is the arena in which a firm conducts its business - customers, competitors, suppliers, and regulators.

TOE has been found to provide a holistic picture for the adoption of technology, its implementation, and factors influencing business innovation-adoption decisions across many different industry contexts (Baker, 2011; Gibbs \& Kraemer, 2004; Hsu et al., 2006; Iacovou et al., 1995; Oliveira \& Martins, 2011; Thong, 1999; Wen \& Chen, 2010; Zhu et al., 2004; Zhu et al., 2003). On the other hand, the TOE framework has been criticized for having unclear major constructs (Wang et al., 2010) and being too generic (Al Nahian Riyadh et al., 2009). Hence the TOE framework needs to be integrated with other models that provide clear constructs and can be applicable to specific contexts. For example, Gangwar et al. (2015) integrated Technology Acceptance Model (TAM) ( Davis (1989)) and TOE to study the cloud computing marketplace. This integration allowed them to identify factors that influence the usage of cloud computing services in organizations (Gangwar et al., 2015). Gangwar et al. (2015) noted that integration of TAM and TOE was not simple because their variables vary across contexts and their significance as well.

Another widely used framework in IS success research that has direct relevance for our study is DeLone and McLean's IS success measures taxonomy (DeLone and McLean, 1992, 2003), commonly known as D\&M model. The original D\&M model elaborates six major categories of IS success measures - System Quality, Information Quality, Information Use, User Satisfaction, Individual Impact, and Organizational Impact. Although the original framework has been widely used by IS researchers for identifying and validating IS success, it has, nevertheless, received criticisms. The main critique of the D\&M model is that it includes both variance and process interpretations leading to "so many potentially confusing meanings that the value of the model is diminished" (Seddon, 1997, page 240). The original framework was updated by the authors themselves ten years later; the new framework adds a new IS Service Quality measure, Intention to Use (Use), and Net Benefits that combines benefits and impact to various stakeholders - individual, organizations, society, etc. To properly apply the D\&M model, DeLone and McLean (2003) emphasized that for each research endeavor, the selection of IS success dimensions and measures should be contingent on the 
objectives and context of the empirical investigation, but, where possible, tested and proven measures should be used. "No single variable is intrinsically better than another, so the choice of success variables is often a function of the objective of the study, the organizational context . . . etc." (DeLone \& McLean, 1992, page 80). The "net benefit" used in the D\&M model is considered too general as a measure for traceability systems implementation, although their argument on considering the different levels of impact helped us to define traceability systems success.

It is possible to combine the TOE framework and D\&M model for a specific context. He and Wang (2014)_ENREF 34 made an interesting comparison of TOE and D\&M model by suggesting that TOE focuses attention on influential factors before (software) adoption, while the D\&M model focuses attention on the success of adoption behavior after adoption. The authors developed a combined TOE-D\&M model that can guide a loop-locked optimum analysis with a feedback mechanism for project management software adoption in enterprises. The combined model can be used for analysis on influential factors for innovation adoption.

CSF research can be traced back to Daniel (1961) who first discussed "success factors" in management literature, and later unpacked by Rockart (1979). O'Brien (2002) observed that senior directors thought CSF were the keys to ensuring successful performance of organizations and to achieve their goals. In this industry and organization level literature, there was no explicit CSF model and the number of critical success factors varied according to the specific research context. Researchers have been critical about the CSF approach. Fortune and White (2006) pointed out that the interrelationships between factors are at least as important as the individual factors but the CSF approach does not provide a mechanism for taking account of these interrelationships.

Despite the deficiencies of the CSF approach, "there is a great deal of attention devoted to the concept in the IS literature as many argue that the use of CSF can have a major impact on the design, development, and implementation of IS" (Williams \& Ramaprasad, 1998, page 858). For example, Fortune and White (2006) identified 27 CSF in their analysis of 63 IS publications. Zhang, et al. (2005) proposed a CSF 
framework specific for ERP success, which comprises of four environments and a total 12 CSF across them: (1) Organizational environment factors include Top Management Support, Company-wide Support, Business Process Reengineering, Effective Project Management, and Organizational Culture; (2) User environment factors include Education and Training, User Involvement, and User Characteristics; (3) System environment factors include ERP Software Suitability, Information Quality, and System Quality; (4) ERP environment factors include ERP Vendor Quality. They found ERP implementation success to be strongly related to User Satisfaction, Individual Impact, Organizational Impact, and Intended Business Performance Improvement.

In sum, the three theoretical models reviewed, i.e. TOE, D\&M model, and CSF framework, provide valuable guidance for studying traceability systems success.

\section{Critical Success Factors for Traceability Systems}

Using the same approach as that Fortune and White (2006) to identify CSF, we reviewed 42 papers relevant to information systems CSF. Table 1 shows the top 15 CSF derived from the literature. Although these CSF were derived from research on information systems in general, they still provided useful guidance for designing the survey instruments for this study. It is interesting to note that most of the CSF identified are related to internal factors, such as top management support, change management, project management, training and education, business process reengineering, user involvement, business plan and vision. Since traceability system implementation involves a variety of external stakeholders, external factors also need to be considered in our study. Here the TOE framework and the D\&M model provides useful guidance.

Insert Table 1 here

Based on our literature review, we compiled a list of relevant factors for our field investigation. A total of 27 factors reported in the literature were considered relevant and included in the survey questionnaire. These 27 factors cover a wide range of issues in systems implementation. The supporting literature for each of these factors is detailed in Appendix 1.

In sum, the literature review reveals two clear gaps. One, there is no study 
specifically focusing on food traceability systems CSFs, particularly in developing countries like China. Two, there are no clearly defined criteria for traceability systems success.

The design of this study was as follows. A pre-study of semi-structured interviews with food enterprises managers was conducted to establish success criteria and CSFs specific to traceability systems in China. This was followed by a survey. The details of the two-stage study and the findings are provided in the subsequent sections.

\section{Pre-Study of Food Traceability Systems}

\section{Pre-Study Interviews}

Four agri-food companies were chosen for the pre-study. They covered a range of products that require traceability in China (e.g. meat, vegetables, fruits, and seafood) and their target markets were both domestic and international. By 2006 all of them had implemented traceability systems with funding from different sources. Six managers from the four companies were interviewed guided by a semi-structured questionnaire. Each interview lasted about 45 minutes. The profile of the four companies and interviewees are presented in Table $2 \mathrm{a}$ and $2 \mathrm{~b}$.

Insert Table $2 \mathrm{a}$ and $2 \mathrm{~b}$ here

The first part of the interview covered information about the company and its traceability system implementation. The second part focused on the views of interviewees on traceability systems CSFs. The final part used open-ended questions. Qualitative data collected from the interviews were transcribed and analyzed.

\section{Pre-Study Results}

\section{Perceived success criteria of traceability systems}

The interview data were analyzed using thematic content analysis method in accordance with D\&M model (DeLone and McLean, 2003). The key CSFs are grouped into three 
impact levels ranging from individual, enterprise to society (also see Table 3):

- $\quad$ Enterprise level

- Society level

- Individual level:

- System users' satisfaction (e.g. employees in the company)

- Information users' satisfaction (e.g. managers, consumers and government officers)

Insert Table 3 here.

At the enterprise level, managers' views covered a wide range of success measures for the organization, such as:

"If the corporate brands and reputation are improved, food products are safer and evaluated well by the consumers meaning the objective of traceability system implementation is achieved and the implementation is a success" (B).

"If the corporate brands, reputation and profit have been improved through the implementation of the system, well, it is a successful implementation" (A).

"If the traceability system can achieve complete tracking, information can be automatically collected and transmitted to the database, enabling the whole food industry chain do a good job, the system implementation is successful" (C).

At the society level, the interviewees shared a range of assessments such as the following:

"First, the system can change the thinking and behavior of enterprises and also can give benefit to the enterprise and workers; second, users can find the information they need 
and the information credibility is high; third, with the enabled traceability, the products are more trusted by consumers"(E).

"If the supply chain partners follow the information collection process in accordance with the system's requirements, consumers can simply, quickly and accurately obtain the information they need, the traceability systems implementation can be considered successful. In addition, the system is available for enterprises for the preservation of information throughout the product life cycle process so consumers can access traceability data when they want" (F).

At the individual level, we need to distinguish between systems users and information users as these two groups have different purposes when using the system. The former refers to the food supply chain workers who use the system to record, input and store traceability data. The later refers to people who access the traceability system to obtain information to meet their respective information needs - food enterprise managers, consumers, government officers, etc. There can be a conflict between traceability system users and information users in what is expected from traceability system. The system users are concerned with system quality issues such as ease of use and adequate functionality for data capturing, whereas the information users are mainly concerned about information quality and demand for comprehensive, complete and reliable food traceability information. This is evident from the interviews. For example, one interviewee noted that some systems users, often food enterprise workers, "are not well educated and skilled in using traceability systems. They just want the traceability systems to be easy and simple to use. They don't really understand or care about information accuracy and completeness" (D). Another manager observed that although "traceability data should be as complete as possible, employees complain about the time and effort to capture and record data," so they "just want to do their job as easily and quickly as possible without any additional effort" (A). On the other hand, consumers and government officers want to have "complete, reliable and accurate food traceability data" (E).

The complexity of traceability system success measures is exacerbated because 
of conflicts in interests of different stakeholders. Food enterprises are profit driven, whereas the government is mainly concerned with food safety and social stability. One manager stated that traceability system implementation, not only "adds additional workload to our existing procedures, but also costs more money for hardware, software and labor input" (C) and "we are implementing traceability system mainly due to the pressure from the government and for increasing our firm's reputation" (C). However, the manager $(\mathrm{F})$ from Company IV confirmed the benefit of traceability system because it "helps the company to track down the problems and clearly identify who is responsible if anything goes wrong."

In sum, the findings show the complexity involved in measuring traceability system success. Also, they suggest that such a measure ought to be multi-leveled because traceability system success can affect society, enterprises, and individuals.

\section{Perceived critical success factors}

Based on the thematic content analysis, the following key themes related to the critical success factors are emerged from the interview data:

- Enterprise top management support, all interviewees mentioned this factor, e.g. timely participation by enterprises (F), senior manager's support (D, F); effective management $(\mathrm{E})$, management making correct decisions $(\mathrm{C})$.

- Project management and partner communication, this is evident by effective communications among traceability systems partners $(\mathrm{C}, \mathrm{E})$, a good project manager $(\mathrm{C})$.

- Trust and collaboration among traceability systems partners, this is evident by honesty and trust among food chain enterprises $(\mathrm{C}, \mathrm{E})$, clear responsibilities and close collaboration (D).

- Education and training, this is evident by training of related personnel $(C, D, F)$, Education of workers $(C, F)$.

- System performance, this is evident by traceability systems quality and usability (A, B, D), system and staff cost (B, D), system availability, easy operation (A, B), 
system's functions (A, B).

- Policy, guidance, laws, regulations and standards, all interviewees stressed the importance of this factor.

- Government investment and financial support, all interviewees mentioned this factor, e.g. investment in traceability systems equipment and technology $(\mathrm{C}, \mathrm{F})$, financial support (C, F), financial incentives for attracting skilled workers (D).

- Consumer awareness and support, this is evident by government publicity of traceability systems (A, F), society support (D, F), consumers' awareness of food traceability $(\mathrm{F})$.

- The integrity and effectiveness of traceability information, this is evident by the credibility of traceability information and completeness of information (A, B); Level of trust towards traceability information (A, B).

- The standardization of traceability information identification, this is evident by standardization of traceability information for easy identification and input (A, D).

In accordance with the interview data analysis, we found five additional traceability systems CSFs in China that are not covered in the literature: 1) Investment by the government in equipment for traceability systems; 2) Consumer's understanding of food traceability; 3) The effectiveness of traceability information; 4) The integrity of traceability information; 5) Standardization of traceability information. The results of interview data analysis for these CSFs is shown in Table 4

Insert Table 4 here

With the addition of these five specific CSF to the 27 CSF drawn from the literature, we had a total of 32 CSFs for the survey (see Table 5).

Insert Table 5 here

\section{Survey Results}

\section{Administration of the Survey}

Based on the literature and pre-study interviews, a survey instrument with items on 32 
traceability systems CSFs was developed for a questionnaire survey. It was a selfadministered questionnaire. The package the respondents received included the following:

i) A cover letter introducing the contents, the purpose and significance of this study. The criteria of "traceability system implementation success" and the definition of "critical success factor" for this study were provided to ensure that the participants were clear about what 'traceability system implementation success' meant in the context of this research.

ii) A list of 32 CSFs without any particular order. The respondents were asked to indicate their opinions on the importance of the factors for traceability system success using a 5-point Likert-type scale (1 - not important; 5 - extremely important).

iii) Information about respondents' profile such as their personal and organizational information.

The questionnaire was originally developed in English and then translated into Chinese because most of the CSFs (27 out of 32) were drawn from the literature in English. Four bilingual translators thereafter translated and back-translated the questionnaire. Some ambiguous expressions were ironed out in this process.

In accordance with Saunders, Lewis, and Thornhill (2007), who have argued that pilot tests can be used to improve the content validity and face validity of the questionnaire, the initial questionnaire was tested with four field researchers. Through this pilot test, valuable feedback was collected on issues such as missing options, repetitions, and improper expressions in the questionnaire. The questionnaire was thereafter revised and improved before final distribution.

The target population was managers who experience with traceability systems in food enterprises. Eight-three food enterprises that have implemented traceability systems in Beijing, Shandong, Hainan, and Guangxi were randomly selected from business directories. Survey questionnaires in editable format (Microsoft Word document) were distributed by email to 398 personnel in these enterprises. The respondents were asked to send back the completed questionnaire. A reminder email 
was sent to the non-respondents two weeks after the questionnaires were first emailed. A total of 129 questionnaires were collected via email attachments in Microsoft Word format of which 124 responses, giving a valid response rate of $31 \%$. The respondents' demographic characteristics are provided in Table 6.

\section{Insert Table 6 here}

As shown in Table 6, over half of the respondents held a management position, and nearly 90 percent of the respondents had traceability systems implementation experience of more than two years.

\section{Descriptive analysis}

The mean values of all 32 factors are more than 3.0 (using 1-5 scale measure) suggesting all the factors are considered important by participants. There are 10 factors with a mean value greater than 4.0; these are the top 10 ranked most important factors, as presented in Table 7.

Insert Table 7 here

The data suggests that the most important factor is "the authenticity of traceability information," which accords with the importance of information authenticity in any IS implementation. Traceability information authenticity not only represents information/system quality but also influences the trust between enterprises and users/consumers. The second and third factors are "complete and adequate food traceability law" and "complete and adequate food traceability standards." The fourth factor is "clear objectives for traceability systems implementation." The fifth factor is “policy guidance for enterprises' traceability systems implementation from government." The sixth factor is "the specific function of traceability systems satisfying users' need." This issue is related to the technical quality of the traceability systems because systems users' satisfaction has always been one of the success factors for IS implementation (DeLone \& McLean, 2003). The seventh factor is "complete and adequate food traceability regulations." The eighth factor, "the standardization of traceability information identification" is distinctively important in traceability systems implementation because of globalization of trade and the lack of international standards 
(Sioen et al., 2007). The ninth factor, "traceability systems implementation being considered by the top management in the corporate strategy" plays an important role in any systems implementation in enterprises as the "top management support" was one of the most frequently mentioned factors in IS success literature. The tenth factor is "the effectiveness of traceability information" which indicates that the information captured in traceability systems should not only be accurate but also effective to meet the traceability systems users' information needs.

\section{Exploratory Factor Analysis}

Before conducting exploratory factor analysis (EFA), two tests were performed to check the possible presence of multicollinearity or correlation among the CSF: the KasierMeyer-Olkin (KMO) measuring sampling adequacy, and the Bartlett's test of sphericity for testing the presence of correlation (Ngai et al., 2004). Bartlett's test requires that the significance value should be less than $0.05(p<0.05)$, moreover, the KMO value should be greater than 0.6 (Tabachnick \& Fidell, 2001), but a value of between 0.8 and 0.9 is better. In this study, the KMO value was 0.854 and the Bartlett's test reached statistical significance $(p=.0000)$.

EFA with a varimax rotation was conducted on the 32 items. In the first round, the communalities of all 32 variables were above the 0.5 threshold recommended by Hair et al. (1995). The initial results of the first round EFA contained eight factors with eigenvalues above 1.0, and the proportion of the variance explained by the eight factors was $73.93 \%$. Four variables including V5 (funding for traceability systems implementation from government), V14 (traceability systems implementation being taken into corporate strategy by top management), V15 (clear objectives for traceability systems implementation), V17 (specific and rigorous arrangements for traceability systems implementation), that had less than 0.5 loadings were removed in the second round. In the second EFA, one variable's (V4 policy guidance for enterprises' traceability systems implementation from government) loading was lower than 0.5 . It was removed; therefore, the remaining 27 variables were used for further data analysis.

The final EFA showed that the factor patterns remained constant and a six dimensional CSF explained $71 \%$ of the total variance among the remaining 27 
variables. Table 8 summarizes the results of the factor analysis with variance explained for each factor.

Insert Table 8 here

In order to ensure internal reliability, a reliability assessment was performed using Cronbach's $\alpha$. The values of Cronbach's $\alpha$ for all six dimensions of the CSF for the implementation of traceability systems were above the recommended value of 0.6 (Nunnally, 1978) indicating that this instrument can be considered reliable and internally consistent.

The use of EFA enabled us to eliminate five variables from the original 32 because of the small value of their factor loading (lower than 0.5), and identify the six dimensions of variables. After six dimensions of critical success factors were extracted from EFA analysis as shown in Table 8, they were labeled based on the characteristics of variables by authors. The classifications were further validated by two other relevant experts.

\section{Discussion}

Here we discuss the six dimensions of CSF specific to traceability systems in the context of China, based on the survey data analysis.

CSF 1: Laws, regulations and standards. This encompasses three variables that were related to the laws, regulations and standards of food safety and food traceability. This factor can be argued to be unique to China because of the current underdeveloped and inadequate food safety regulations and standards.

Although the Chinese government has enacted a series of food safety laws and regulations in recent years, due to lack of an effective coordinated enforcement mechanism and approach, food safety incidents still occur frequently (Jia \& Jukes, 2013; Mao et al., 2015). The food safety management structure at the national and local levels in China still have shortcomings (Jia \& Jukes, 2013). Both traceability systems 
regulation and enforcement need improvement.

CSF 2: Government support. This encompasses two variables that were related to the importance of equipment investment and technology support for enterprises implementing systems from the government. This factor is unique to China due to the high technology and laboring costs and low financial rewards. This factor is mentioned by a number of researchers (e.g. Jiang, 2007; Pizzuti and Mirabelli 2015) but has not been empirically tested.

In China, food traceability systems are still in an early stage of development, and the enterprises, especially SMEs, have limited knowledge about food traceability and system implementation, and also lack of motivation due to yet unrealized benefits (Jia \& Jukes, 2013; Mao et al., 2015). Therefore, government support - funding, technology, equipment, and tax concessions - becomes the driver for adoption of traceability systems in many food enterprises.

CSF 3: Consumer knowledge and support. This encompasses three variables related to consumers' understanding and support of food traceability implementation. Consumer awareness, knowledge, and willingness to pay more for traceable food, value-added labeling, etc. can become an important driver for traceability systems success, especially in developing countries like China. It is a societal challenge to raise awareness of the advantages of food traceability among consumers and gain their support. It can also be argued that there is an increased role and responsibility for consumers in implementing food safety management systems (Mensah and Julien (2011).

CSF 4: Top management, company-wide and vendor support. This encompasses five variables that explain the importance of support from top management and department staff and also the vendors for the system implementation. This CSF has been recognized in many IS implementation studies (see Table 1).

Davenport (1998) posited that if the development of an enterprise system is not carefully controlled by management, management may soon find itself under the control of the system. Top management is responsible for articulating a vision and providing 
sufficient financial support and adequate resources for building a successful system, the support of management is vital to ensure high priority is given to the traceability systems implementation. Apart from financial support and adequate resources, psychological or behavioral support is also important to the smooth implementation of the system, especially if there is significant resistance from the staff involved. Since traceability systems are enterprise-wide IS, it is imperative to get support from all functional segments of the organization, as well as to ensure effective vendor support and training in case the traceability systems are purchased as software or services on the cloud platform.

CSF 5: Effective management and communication. This encompasses seven variables related to system implementation management, caliber of administrators, quality and communication between upstream and downstream companies. This CSF has been recognized in many IS implementation studies (see Table 1) and is also confirmed to be critical in traceability systems implementation in China.

As traceability systems implementation involves people, technology and process, effective traceability systems management and communication has been recognized as one of the CSFs. According to Badiru (1988), communication is a prerequisite for the cooperation of employees in the successful implementation of any system. Mendel (1999) stated that strong communication throughout the various stages of the system implementation process is essential in allowing employees to understand what is going on in the project, why change is necessary, and how it will benefit the organization. In addition, an effective communication plan leads to the development of trust and the exchange of information needed for process changes and the acceptance of the new technology (Amoako-Gyampah \& Salam, 2004). For successful traceability systems implementation, effective communications with the upstream and downstream enterprises must be maintained.

CSF 6: Information quality and system quality. This encompasses seven variables that dealt with traceability information quality and system quality. Although this factor is also important for other types of information systems, they are specifically critical to traceability systems success and to China because of the food safety concerns. 
Therefore the accuracy and credibility of information in food traceability systems are ultimately essential.

The information and system quality have been recognized as a CSF for IS in the D\&M model (DeLone \& McLean, 2003), however, this was a particularly important factor in the context of traceability systems implementation that deserves more attention. Traceability systems are often food chain based inter-organizational systems, the traceability information must be accurate, complete, reliable and in the correct format for all chain-based traceability systems. For example, incorrect data input in upstream traceability systems would make the downstream chain traceability systems produce unreliable traceability information. Another reason is the complexity of devices used to collect and process traceable data such as: RFID, smart device, and IoT technologies. These emerging technologies and the different degree of adoption by global chain companies, can led to problems in compatibility, communication, as well as high costs associated with processing and communicating traceable information. System quality represents the technical aspect of traceability systems which can have a significant impact on its initial adoption and continuing operations.

Although these six dimensions of CSF have been mentioned by a number of researchers (see Table 5), none of previous research has systematically and empirically validated these factors as critical success factors specifically in the context of food traceability systems implementation in China. Therefore, this study makes additional contributions to existing literature by providing a comprehensive set of critical success factors that are theoretically justified and empirically validated. Table 9 provides an overview of the survey results, dimensions of critical success factors unique to traceability systems and /or specific to China, and their contributions to existing literature.

Insert Table 9 here

To further understand the findings from the EFA analysis, the TOE framework by Tornatzky and Fleischer (1990) was applied to map out the six dimensions of CSF discussed above. It was found that three out of six dimensions belong to the environment aspect of TOE, reflecting a strong external push (influence) for traceability 
systems in Chinese food enterprises and included four external driving forces: industry, competitors, customers and government. Two dimensions are related to the organizational aspect of TOE including top management support and effective information communication; and one dimension is related to the technology aspect of TOE, which refers to information quality and systems quality (system maturity and usability). Information quality may also be considered as being related to the organizational aspect, if data is manually entered into the traceability systems system. Based on the results, a framework of critical success factors for traceability systems in the context of China is derived and shown in Figure 1.

Insert Figure 1 here

The framework enriches the "net benefit" notion of the D\&M model by elaborating the critical role of external stakeholders, e.g. government push and customer pull for traceability systems success. It also confirms "information quality" of the D\&M model and identifies this as a critical factor specifically influencing the success of traceability systems. Vis-à-vis the existing Chinese literature, the framework confirms legislation, law and standards, traceability data collection and processing, lack of financial support as main issues. It provides useful guidance for the inclusion of multilevel measures for information systems success research. It offers a structured analysis of important factors that may be applicable to traceability systems implementation in different countries, but also considers the context of the developing counties like China.

Regarding generalizability of the results, as this CSF framework is based on the empirical evidence collected in China, it may not be applicable to developed countries due to differences in political environment, social systems and economic development. Nevertheless, we strongly believe that the traceability systems success measures, and the CSF framework for traceability systems implementation can apply to other developing countries. 


\section{Conclusions and Implications}

Traceability in the food supply chain is still an underdeveloped field (Bosona \& Gebresenbet, 2013) and it has no common theoretical framework (Karlsen et al., 2013). Research so far on what constitutes its success, how to measure it, and what the CSFs are still remains an academic and practical challenge.

Before we can take on this challenge, we need to first address the essential question: What the criteria for measuring traceability systems implementation success ought to be? The analysis presented in this study captures the complexity of traceability systems success measures. It shows the need for measures at three levels - enterprise, society, and individual. At the enterprise level, success measures were enterprise reputation, brand name and profitability; at the society level, measures were food safety and quality for consumers; and at the individual level, measures covered both system users' satisfaction, and information users' satisfaction. These measures cover the considerations of key stakeholders including consumers, government agencies, and food enterprises, traceability system users, and traceability system information users. This finding may also be applicable to other types of IS, such as health care information management systems and e-government systems.

This study also developed further insight into the distinctive quality of traceability information in the global supply chain and the importance of information users' satisfaction as a traceability systems CSF. In measuring information users' satisfaction in assessing traceability systems success, managers identified variables including: effectiveness of traceability information, integrity of traceability information, authenticity of traceability information, standardization of traceability information identification. These features are likely to be unique to traceability systems, as they seem to have not been fully reported in the existing literature.

Many CSFs for IS were identified in the literature and confirmed in this study, but to ascertain the underlying structure of the factors for traceability systems implementation, this study employed EFA data reduction technique, which revealed six key CSF dimensions for traceability systems. Mapping against the TOE model showed that three 
of the six CSF factors were related to the environment context. Environmental concerns are a powerful external driving force for traceability systems implementation. This finding calls for stronger governmental intervention, specially in China and other developing countries where laws, regulations, government support and consumer awareness are still not fully developed.

Two of the six CSF factors were related to organizational factors. Organizational factors play important roles in enabling the successful implementation of traceability systems. The importance of organizational context in IS success has been well recognized in previous research, e.g. Thong, (1999). Only one of the six CSF was related to the technological factor, although technological factors have been identified as critical in many other IS studies. For traceability systems success, the technology factor appears to play a less critical role than environmental and organizational factors. This confirms Storøy Storøy et al. (2013) contention that the main obstacle for successful and efficient implementation of traceability in food product chains is organizational, not technical.

This study also has important practical implications for policy makers and business practitioners. Since an external driving force is critical for traceability systems success, laws, regulations and standards and government support and guidance should be given more attention. In particular attention should be paid to harmonizing laws and standards with international laws and standards for food safety and traceability, effective coordinating for global food risk alerts and recalls, effective monitoring and quality control. For countries where food safety law, regulations and policies are underdeveloped and not harmonized with the international regulations and standards, it may be necessary, as the example of China shows, to speed up the food traceability systems implementation through official enforcement, guidance and incentives.

The food enterprises are obliged to take social responsibility by fully implementing food safety policies, procedures and systems and following international and national traceability standards. This could mean radical changes in current processes, systems and culture. Consumer knowledge and support was another external critical factor that influences traceability systems implementation success. The government, and food enterprises at all tiers of the supply chain should proactively 
promote and publicize the benefits of using traceability systems and traceable food products. Willingness to pay for traceable products by consumers will ultimately drive the proliferation and implementation of traceability systems.

Information quality is particularly important to the success of traceability systems due to the chain-based nature of traceability systems. Measures needed to be taken to ensure traceable information authenticity and accuracy. This could include traceability systems users' training, skills development, compatibility in data collection and communication technologies and integration of systems at different levels and regions.

\section{References}

Akkermans, H. \& Helden, K. V. (2002). Vicious and Virtuous Cycles in ERP Implementation: a Case Study of Interrelations between Critical Success Factors. European Journal of Information Systems(11): 35-46.

Al-Mashar, M. i., Al-Mudimigh, A. \& Zairi, M. (2003). Enterprise Resource Planning: A Taxonomy of Critical Factors. European Journal of Operational Research, 146(2): 352-364.

Al Nahian Riyadh, M., Akter, S. \& Islam, N. (2009). The adoption of e-banking in developing countries: A theoretical model for SMEs. International review of business research papers, 5(6): 212-230.

Amoako-Gyampah, K. \& Salam, A. F. (2004). An Extension of the Technology Acceptance Model in An ERP Implementation Environment. Information and Management, 41(6): 731-745.

Aung, M. M. \& Chang, Y. S. (2014). Traceability in a food supply chain: Safety and quality perspectives. Food Control, 39: 172-184.

Badia-Melis, R., Mishra, P. \& Ruiz-García, L. (2015). Food traceability: New trends and recent advances. A review. Food Control, 57: 393-401.

Badiru, A. B. (1988). Successful Initiation of Expert Systems Projects. IEEE Transactions on Engineering Management, 35(3): 186-190.

Baker, J. (2011). The TOE Framework Information Systems Theory: Explaining and Predicting Our Digital Society (Vol. 1, pp. 231-370). New York: Springer.

Bollen, A. F., Riden, C. P. \& Cox, N. R. (2007). Agricultural supply system traceability, Part I: Role of packing procedures and effects of fruit mixing. Biosystems Engineering, 98(4): 391-400.

Bosona, T. \& Gebresenbet, G. (2013). Food traceability as an integral part of logistics management in food and agricultural supply chain. Food Control, 33(1): 32-48.

Caswell, J. A. (2006). Quality Assurance, Information Tracking, and Consumer Labelling. Marine Pollution Bulletin, 53: 650-656.

CCSFA. (2007). Phase Report of Food Safety Traceability Research. Paper presented at the Annual Meeting of Circulation Food Safety, Beijing.

Chen, H. (2008). GS1 System Applies in Hainan Aquatic Product Quality and Safety Traceability System. World Standardization \& Quality Management, 8: 56-58. 
Chen, R. S., Chen, C. C. \& Yeh, K. C. (2008). Using RFID Technology in Food Produce Traceability. WSEAS TRANSACTIONS on INFORMATION SCIENCE and APPLICATIONS, 5(11): 1551-1560.

Chetcuti, H. R. (2008). ERP Implementation: A Multi-stakeholder Analysis of Critical Success Factors. Paper presented at the WICT Proceedings.

Chryssochoidis, G., Karagiannaki, A., Pramatari, K. \& Kehagia, O. (2009). A cost-benefit evaluation framework of an electronic-based traceability system. British Food Journal, 111(6): 565-582.

Cimino, M. G. C. A. \& Lazzerini, B. (2005). Cerere: An Information System Supporting Traceability in the Food Supply Chain. Paper presented at the Seventh IEEE International Conference on E-Commerce Technology Workshops, Munich, Germany.

D'Amico, P., Armani, A., Castigliego, L., Sheng, G., Gianfaldoni, D. \& Guidi, A. (2014). Seafood traceability issues in Chinese food business activities in the light of the European provisions. Food Control, 35(1): 7-13.

Dan, P. K. (2009). ERP in Indian SME's: A Post Implementation Study of the Underlying Critical Success Factors. International Journal of Management Innovation System, 1(2:E1): 1-9.

Daniel, D. R. (1961). Management Information Crisis. Harvard Business Review, 39(5): 111-116.

Davenport, T. H. (1998). Putting the Enterprise Into the Enterprise System. Harvard Business Review, 76(4): 121-131.

Davis, F. D. (1989). Perceived usefulness, perceived ease of use, and user acceptance of information technology. MIS Quarterly, 13(3): 319-340.

DeLone, W. H. \& McLean, E. R. (1992). Information systems success: The quest for the dependent variable. Information Systems Research, 3(1): 60-95.

DeLone, W. H. \& McLean, E. R. (2003). The DeLone and McLean Model of Information Systems Success: A Ten-Year Update. Journal of Management Information Systems, 19(4): 9-30.

Doom, C., Milis, K., Poelmans, S. \& Bloemen, E. (2010). Critical Success Factors for ERP Implementations in Belgian SMEs. Journal of Enterprise Information Management, 23(3): 378-406.

Finney, S. \& Corbett, M. (2007). ERP Implementation: A Compilation and Analysis of Critical Success Factors. Business Process Management Journal, 13(3): 329-347.

Fortune, J. \& White, D. (2006). Framing of project critical success factors by a systems model. International Journal of Project Management, 24(1): 53-65.

Gangwar, H., Date, H. \& Ramaswamy, R. (2015). Understanding determinants of cloud computing adoption using an integrated TAM-TOE model. Journal of Enterprise Information Management, 28(1): 107-130.

Gibbs, J. L. \& Kraemer, K. L. (2004). A Cross - Country Investigation of the Determinants of Scope of E-commerce Use: An Institutional Approach. Electronic Markets, 14(2): 124-137.

Government. (2015). Food Safety Law of the People's Republic of China (in Chinese). Retrieved $17 \quad$ July 2016, 2016, from http://www.npc.gov.cn/npc/zfjc/zfjcelys/2015-04/25/content 1992458.htm

Han, Y. \& Qiao, J. (2009). Influence Factors on Consumers' Attitude and Willingness to Buy Traceable Foods in China: A Test and Analysis on the Survey from Beijing. Technology Economics, 28(4): 37-43,53. 
He, Y. \& Wang, W. (2014). BPM Software Adoption in Enterprises based on TOE Framework and IS Success Model. Computer Modelling \& New Technologies, 18(12C): 195-200

Howard, A., Edge, J. \& Grant, M. (2012). Forging Stronger Links: Traceability and the Canadian Food Supply Chain: The Conference Board of Canada.

Hsu, P. F., Kraemer, K. \& Dunkle, D. (2006). Determinants of E-Business Use in U.S. Firms. Int. J. Electron. Commerce, 10(4): 9-45.

Iacovou, C. L., Benbasat, I. \& Dexter, A. S. (1995). Electronic data interchange and small organizations: adoption and impact of technology. MIS Q., 19(4): 465-485.

Jia, C. \& Jukes, D. (2013). The national food safety control system of China - A systematic review. Food Control, 32(1): 236-245.

Jiang, D. (2007). Success Factors Research of Information Systems in the Mechanical Manufacturers in Kunming (in Chinese). (Master Thesis), Zhejiang University, Hanzhou, China.

Jooken, K. \& Lauryssen, S. (2006). Aquaculture and Labelling of Fish: No Fish Without Bones. Test Aankoop (496): 28-30

Karlsen, K. \& Senneset, G. (2006). Traceability: Simulated Recall of Fish Products. In J. Luten, C. Jacobsen, K. Bekaert, A. Saebo \& J. Oehlenschlager (Eds.), Seafood Research from Fish to Dish. Quality, Safety and Processing of Wild and Farmed Fish (pp. 251-261): Wageningen: Wageningen Academic Publisher.

Karlsen, K., Sørensen, C., Forås, F. \& Olsen, P. (2011). Critical criteria when implementing electronic chain traceability in a fish supply chain. Food Control, 22(8): 1339-1347.

Karlsen, K. M., Dreyer, B., Olsen, P. \& Elvevoll, E. O. (2013). Literature review: Does a common theoretical framework to implement food traceability exist? Food Control, 32(2): 409-417.

Kelepouris, T. (2007). RFID-enabled Traceability in the Food Supply Chain. Industrial Management \& Data Systems, 107(2): 183-200.

Lee, S. \& Kim, K.-J. (2007). Factors Affecting the Implementation Success of Internetbased Information Systems. Computers in Human Behavior, 23(4): 1853-1880.

Li, X. (2006). The Urgency and Feasibility for Establish China Aquatic Products Traceability System (in Chinese). China Fishery, 9: 21-26.

Liao, P. A., Chang, H. H. \& Chang, C. Y. (2011). Why is the food traceability system unsuccessful in Taiwan? Empirical evidence from a national survey of fruit and vegetable farmers. Food Policy, 36(5): 686-693.

Lin, 1. \& Zhou, D. (2005). On the Construction of Food Quality and Safety Traceability System (in Chinese). Commercial Research(21): 41-44.

Liu, R., Pieniak, Z. \& Verbeke, W. (2013). Consumers' attitudes and behaviour towards safe food in China: A review. Food Control, 33(1): 93-104.

Loh, T. C. \& Koh, S. C. L. (2004). Critical Elements for A Successful Enterprise Resource Planning Implementation in Small-and Medium-Sized Enterprises. International Journal of Production Research, 42(17): 3433-3455.

Mao, B., He, J., Cao, J., Bigger, S. W. \& Vasiljevic, T. (2015). A Framework for Food Traceability Information Extraction Based on a Video Surveillance System. Procedia Computer Science, 55: 1285-1292.

McMeekin, T. A. \& Baranyi, J. (2006). Information Systems in Food Safety Management. International Journal of Food Microbiology, 112: 181-194.

Mendel, B. (1999). The Portal Panacea. Info World, 28(31): 28-29. 
Mensah, L. D. \& Julien, D. (2011). Implementation of food safety management systems in the UK. Food Control, 22(8): 1216-1225.

Miraglia, M. (2004). Detection and Traceability of Genetically Modified Organisms in the Food Production Chain. Food and Chemical Toxicology, 42(7): 1157-1180.

Morgan, L. \& Finnegan, P. (2007). How Perceptions of Open Source Software Influence Adoption: An Exploratory Study. Paper presented at the Prodeedings of the 15th European Conference on Information Systems, University of St Gallen, Switzerland.

Nah, F. F. H. \& Delgado, S. (2006). Critical Success Factors for Enterprise Resource Planning Implementation and Upgrade. The Journal of Computer Information Systems, ProQuest Science Journals, 46(5): 99-113.

Nah, F. F. H. \& Lau, J. L. S. (2001). Critical Factors for Successful Implementation of Enterprise Systems. Business Process Management Journal, 7(3): 285-296.

Ngai, E. W. T., Cheng, T. C. E. \& Ho, S. S. M. (2004). Critical Success Factors of Webbased Supply-Chain Management Systems: An Exploratory Study. Production Planning \& Control, 15(6): 622-630.

Nunnally, J. C. (1978). Psychometric Theory (2nd edition). New York: McGraw-Hill.

O'Brien, J. A. (2002). Management Information Systems: Managing Information Technology in the E-Business Enterprise(5th edition). New York: Mc Graw Hill Irwin.

Oliveira, T. \& Martins, M. F. (2011). Literature Review of Information Technology Adoption Models at Firm Level The Electronic Journal Information Systems Evaluation: ECIME 2010 Special Issue, 14(1): 110-121.

Peets, S., Gasparin, C. P., Blackburn, D. W. K. \& Godwin, R. J. (2009). RFID Tags for Identifying and Verifying Agrochemicals in Food Traceability Systems. Precision Agriculture, 10(5): 382-394.

Pizzuti, T. \& Mirabelli, G. (2015). The Global Track \&Trace System for food: General framework and functioning principles. Journal of Food Engineering, 159: 16-35.

Regattieri, A., Gamberi, M. \& Manzini, R. (2007). Traceability of food products: General framework and experimental evidence. Journal of Food Engineering, 81(2): 347356.

Remus, U. (2007). Classification of Success Factors for Implementing Enterprise Portals-A Comparison with ERP Implementation. Business Process Management Journal, 13(4): 538-552.

Rockart, J. F. (1979). Chief Executives Define Their Own Data Needs. Harvard Business Review., 57(2): 81-93.

Roth, A. V., Tsay, A. A., Pullman, M. E. \& Gray, J. V. (2008). Unraveling the food supply chain: strategic insights from China and the 2007 recalls. Journal of Supply Chain Management, 44(1): 22-39.

Saunders, M. N., Lewis, P. \& Thornhill, A. (2007). Research methods for business students (fourth ed.). London: Pearson Professional Limited.

Seddon, P. B. (1997). A respecification and extension of the DeLone and McLean model of IS success. Information Systems Research, 8(3): 240-253.

Sioen, I., Verbeke, W., De Henauw, S., Parmentier, K., Raemaekers, M., Willems, J. \& Van Camp, J. (2007). Determining the Origin of Seafood Products on the Belgian Market: Challenges to Traceability and Database Management. The Open Food Science Journal, 2007(1): 33-42.

Storøy, J., Thakur, M. \& Olsen, P. (2013). The TraceFood Framework - Principles and 
guidelines for implementing traceability in food value chains. Journal of Food Engineering, 115(1): 41-48.

Sumner, M. (1999). Critical Success Factors in Enterprise Wide Information Management Systems Projects. Paper presented at the Proceedings of the 1999 ACM SIGCPR Conference on Computer Personnel Research, Milwaukee.

Tabachnick, B. G. \& Fidell, L. S. (2001). Using multivariate statistics (4th edn). New York: HaperCollins.

Thong, J. Y. L. (1999). An Integrated Model of Information Systems Adoption in Small Businesses. Journal of Management Information Systems, 15(4): 187-214.

Tornatzky, L. G., Fleischer, M. \& Chakrabarti, A. K. (1990). The processes of technological innovation. Lexington, Mass.: Lexington Books.

Wang, Y.-M., Wang, Y.-S. \& Yang, Y.-F. (2010). Understanding the determinants of RFID adoption in the manufacturing industry. Technological Forecasting and Social Change, 77(5): 803-815.

Wen, K.-W. \& Chen, Y. (2010). E-business value creation in Small and Medium Enterprises: a US study using the TOE framework. International Journal of Electronic Business, 8(1): 80-100.

Williams, J. J. \& Ramaprasad, A. (1998). The Utilization of Critical Success Factors: A Profile. Paper presented at the Proceedings of the 29th annual meeting of the Decision Sciences.

Xu, J., Deng, H. \& Zhou, H. (2008). Analyze Institution Building of Agricultural Products Quality and Safety Traceability. Journal of Hunan Agricultural University (Social Sciences), 9(2): 24-28.

Xu, L. \& Wu, L. (2008). Research of Consumer Behavior in Food Traceability System: A Literature Review. Consumer Economics, 24(5): 93-97.

Yeoh, W., Gao, J. \& Koronios, A. (2007). IFIP International Federation for Information Processing, Volume 255. In L. Xu, A. Tjoa \& S. Chaudhry (Eds.), Research and Practical Issues of Enterprise Information Systems Volume 2 (pp. 1353-1367). (Boston:Springer).

Zen, Y. (2005). Barcode Vegetables Explore the Road of Quality and Safety Traceability in China (in Chinese). Vegetables, 10:1-4.

Zhai, L., Hua, P. \& Hu, R. (2008). Structure Equation Modeling of Critical Success Factors for IS/IT Projects. Journal of Systems Engineering, 23(3): 352-356.

Zhang, B., Huang, Z. \& Ye, C. (2007). Design and Implement of Vegetable Quality and Safety Traceability System. Food Science, 28(8): 573-577.

Zhang, L., Lee, M. K. O., Zhang, Z. \& Banerjee, P. (2002). Critical Success Factors of Enterprise Resource Planning Systems Implementation Success in China. Paper presented at the Proceedings of the 36th Hawaii International Conference on System Sciences(HIC'03) IEEE.

Zhang, L. \& Wei, D. (2009). Animal Identification and Problems and Suggestions for Traceability System Implementation. Chinese Journal of Animal Health Inspection, 26(6): 20-21.

Zhang, Z., Lee, M. K. O., Huang, P., Zhang, L. \& Huang, X. (2005). A Framework of ERP Systems Implementation Success in China: An Empirical Study. International Journal of Production Economics(98): 56-80.

Zhu, K., Kraemer, K. L. \& Dedrick, J. (2004). Information technology payoff in ebusiness environments: An international perspective on value creation of ebusiness in the financial services industry. Journal of Management Information 
Systems, 21(1): 17-54.

Zhu, K., Kraemer, K. L. \& Xu, S. (2003). Electronic Business Adoption by European Firms: A Cross-country Assessment of the Facilitators and Inhibitors.

Zhu, X. (2008). Promote Quality and Safety Traceability System to Ensure Vegetables

Consumption Safety (in Chinese). Vegetables, 7: 34-35. 


\section{Table 1}

\section{Top 15 CSFs for IS Implementation Reported in the Literature}

\begin{tabular}{|c|c|c|}
\hline Critical success factors & $\begin{array}{c}\text { Frequency } \\
(n=42)\end{array}$ & Supporting references \\
\hline 1. Top management support & 31 & $\begin{array}{l}\text { Zhai et al.(2008); Nah and Lau (2001); Zhang et } \\
\text { al. (2002); Finney and Corbett (2007) }\end{array}$ \\
\hline 2. (User)Training and education & 28 & Ngai et al. (2004); Zhang et al. (2005) \\
\hline 3. Change management & 24 & $\begin{array}{l}\text { Loh and Koh (2004); Zhai et al.(2008); Finney } \\
\text { and Corbett (2007); Doom et al. (2010) }\end{array}$ \\
\hline 4. Project management & 23 & $\begin{array}{l}\text { Akkermans and Helden (2002); Al-Mashar et al. } \\
\text { (2003) }\end{array}$ \\
\hline $\begin{array}{ll}\text { 5. } & \begin{array}{l}\text { Business process } \\
\text { reengineering }\end{array} \\
\end{array}$ & 16 & Nah and Lau (2001); Zhang et al. (2005) \\
\hline $\begin{array}{l}\text { 6. Project team } \\
\text { competence/capability }\end{array}$ & 16 & $\begin{array}{c}\text { Dan (2009); Doom et al. (2010); Loh and Koh } \\
\text { (2004); Sumner (1999) }\end{array}$ \\
\hline 7. Communications & 14 & Ngai et al. (2004); Zhai et al.(2008) \\
\hline 8. Project champion & 13 & Yeoh et al. (2007); Dan (2009) \\
\hline 9. User involvement & 11 & Yeoh et al. (2007); Zhai et al.(2008) \\
\hline 10. Business plan and vision & 9 & Nah and Lau (2001); Yeoh et al. (2007) \\
\hline 11. Testing and troubleshooting & 7 & $\begin{array}{l}\text { Finney and Corbett (2007); Nah and Lau } \\
\text { (2001) }\end{array}$ \\
\hline 12. Clear goals and objectives & 6 & $\begin{array}{l}\text { Doom et al. (2010); Doom et al. (2010); Nah } \\
\text { and Delgado (2006) }\end{array}$ \\
\hline 13. Vendor support & 5 & Chetcuti (2008); Zhang et al. (2005) \\
\hline 14. Careful package selection & 5 & Akkermans and Helden (2002); Remus (2007) \\
\hline 15. Use of consultants & 5 & Doom et al. (2010); Yeoh et al. (2007) \\
\hline
\end{tabular}


Table 2a

\section{Company Profile}

\begin{tabular}{|l|l|l|l|l|}
\hline & Company I & Company II & Company III & Company IV \\
\hline $\begin{array}{l}\text { Traceable } \\
\text { products }\end{array}$ & Aquatic products & Meats & $\begin{array}{l}\text { Vegetables and } \\
\text { fruits }\end{array}$ & Fruits \\
\hline $\begin{array}{l}\text { System } \\
\text { adoption year }\end{array}$ & 2006 & 2006 & 2008 & 2007 \\
\hline $\begin{array}{l}\text { System } \\
\text { developer }\end{array}$ & IT vendor & IT vendor & IT vendor & IT vendor \\
\hline Funding body & EU program & $\begin{array}{l}\text { National } 863 \\
\text { Project }\end{array}$ & $\begin{array}{l}\text { Beijing Municipal } \\
\text { Bureau of } \\
\text { Agriculture }\end{array}$ & $\begin{array}{l}\text { Beijing Municipal } \\
\text { Bureau of } \\
\text { Agriculture }\end{array}$ \\
\hline Target market & China and abroad & $\begin{array}{l}\text { China, Japan, } \\
\text { Korea, and EU }\end{array}$ & $\begin{array}{l}\text { Mainland China, } \\
\text { Hong Kong, } \\
\text { Singapore }\end{array}$ & Mainland China \\
\hline
\end{tabular}

Table 2b

\section{Interviewee Profile}

\begin{tabular}{|l|l|l|l|}
\hline Interviewee & Company I & Position & Type of user \\
\hline A & I & $\begin{array}{l}\text { Assistant Chief } \\
\text { Executive }\end{array}$ & Information user \\
\hline B & I & $\begin{array}{l}\text { Production } \\
\text { Manager }\end{array}$ & $\begin{array}{l}\text { System and } \\
\text { information user }\end{array}$ \\
\hline C & II & IT manager & System user \\
\hline D & III & $\begin{array}{l}\text { Assistant Chief } \\
\text { Executive }\end{array}$ & $\begin{array}{l}\text { Information and } \\
\text { system user }\end{array}$ \\
\hline E & III & Deputy Manager & $\begin{array}{l}\text { Information and } \\
\text { system user }\end{array}$ \\
\hline F & IV & $\begin{array}{l}\text { Assistant Chief } \\
\text { Executive }\end{array}$ & Information user \\
\hline
\end{tabular}


Table 3

\section{Success Criteria for Traceability Systems Drawn from Interviews}

\begin{tabular}{|c|c|c|}
\hline $\begin{array}{l}\text { Key criteria emerged from } \\
\text { interviews }\end{array}$ & $\begin{array}{l}\text { Level of } \\
\text { Impact }\end{array}$ & Evidence from interviews \\
\hline $\begin{array}{l}\text { - Enhanced enterprise brand, } \\
\text { reputation } \\
\text { - } \text { Profitability } \\
\text { - Consumer trust }\end{array}$ & Enterprise & $\begin{array}{ll}- & \text { Brand and reputation improved (A, B, E, F) } \\
\text { - } & \text { Profit increased (A, C, E, F) } \\
\text { - } & \text { Products are more trusted by consumers }(\mathrm{B}, \mathrm{E})\end{array}$ \\
\hline $\begin{array}{ll}\text { - } & \text { Improved food quality and } \\
\text { - } & \text { Consety } \\
\text { - } & \text { Access to food traceability } \\
\text { information }\end{array}$ & Society & $\begin{array}{ll}\text { - } & \text { Improved food quality and safety }(\mathrm{A}, \mathrm{B}, \mathrm{D}, \mathrm{E}, \mathrm{F}) \\
\text { - } & \text { Increased food safety awareness by consumers } \\
& (\mathrm{A}, \mathrm{B}, \mathrm{C}) \\
\text { - } & \text { Consumers can simply, quickly and accurately } \\
\text { obtain the information they need }(\mathrm{C}, \mathrm{F})\end{array}$ \\
\hline - Information user satisfaction & \multirow[t]{2}{*}{ Individual } & $\begin{array}{ll}- & \text { Information credibility }(\mathrm{E}, \mathrm{F}) \\
- & \text { Data accuracy }(\mathrm{E}, \mathrm{F}) \\
- & \text { Information meets users' need }(\mathrm{C}, \mathrm{E}) \\
\text { - } & \text { Completeness of tracing and tracking } \\
& \text { information }(\mathrm{B}, \mathrm{C}) \\
\end{array}$ \\
\hline - System user satisfaction & & $\begin{array}{ll}\text { - } & \text { System user satisfaction }(\mathrm{A}, \mathrm{B}, \mathrm{C}) \\
\text { - } & \text { Information automatically collected and } \\
& \text { transmitted }(\mathrm{B}, \mathrm{C}) \\
\text { - } & \text { Good performance of software (E, F) }\end{array}$ \\
\hline
\end{tabular}

\section{Table 4}

\section{Additional CSFs Drawn from Interview Data}

\begin{tabular}{|l|l|}
\hline New CSF not covered in literature & \multicolumn{1}{c|}{ Evidence } \\
\hline $\begin{array}{l}\text { 1. Investment by the government in } \\
\text { equipment for traceability } \\
\text { systems }\end{array}$ & $\begin{array}{l}\text { Investment in equipment and technology (C, F), } \\
\text { financial support (C, F, D). }\end{array}$ \\
\hline $\begin{array}{l}\text { 2. Consumer's understanding of } \\
\text { food traceability }\end{array}$ & $\begin{array}{l}\text { Government publicity of traceability systems (A, } \\
\text { F), society support (D, F), consumers' awareness of } \\
\text { food traceability (F) }\end{array}$ \\
\hline $\begin{array}{l}\text { 3. The effectiveness of traceability } \\
\text { information }\end{array}$ & $\begin{array}{l}\text { Level of trust for traceability information (A, B, D, } \\
\text { E), the usefulness of traceability information (D). }\end{array}$ \\
\hline $\begin{array}{l}\text { 4. The integrity of traceability } \\
\text { information }\end{array}$ & $\begin{array}{l}\text { The credibility of traceability information and } \\
\text { completeness of information (A, B), honesty and } \\
\text { trust among food chain enterprises (C, E), clear } \\
\text { responsibilities and close collaboration (D) }\end{array}$ \\
\hline $\begin{array}{l}\text { 5. The standardization of } \\
\text { traceability information }\end{array}$ & $\begin{array}{l}\text { Standardization of traceability information for easy } \\
\text { identification and input (A, D) }\end{array}$ \\
\hline
\end{tabular}


Table 5

\section{The Survey Instrument and Supporting Sources}

\begin{tabular}{|c|c|c|}
\hline \multirow{2}{*}{$\begin{array}{l}\text { Factors Affecting Traceability Systems } \\
\text { Implementation }\end{array}$} & \multicolumn{2}{|l|}{ Source } \\
\hline & Literature & Interview \\
\hline 1. Complete and adequate food traceability regulations & $\begin{array}{l}\text { Thakur and Hurburgh } \\
\text { (2009) }\end{array}$ & \\
\hline 2. Complete and adequate food traceability laws & $\begin{array}{l}\text { Thakur and Hurburgh } \\
\text { (2009) }\end{array}$ & \\
\hline 3. Complete and adequate food traceability standards & $\begin{array}{l}\text { Thakur and Hurburgh } \\
\text { (2009); Roth et al. (2008) }\end{array}$ & \\
\hline $\begin{array}{l}\text { 4. Policy guidance for enterprises' traceability systems } \\
\text { implementation from government }\end{array}$ & Jiang (2007) & \\
\hline $\begin{array}{l}\text { 5. Funding for traceability systems implementation from } \\
\text { government }\end{array}$ & Jiang (2007) & \\
\hline $\begin{array}{l}\text { 6. Equipment investment for traceability systems } \\
\text { implementation from government }\end{array}$ & & $\mathrm{X}$ \\
\hline $\begin{array}{l}\text { 7. Technology support for traceability systems } \\
\text { implementation from government }\end{array}$ & CCSFA (2007) & \\
\hline $\begin{array}{l}\text { 8. Food traceability publicity to consumers from the } \\
\text { government }\end{array}$ & $\begin{array}{l}\text { (Jiang (2007); Xu and Wu } \\
(2008))\end{array}$ & \\
\hline 9. Willingness to pay from consumers for traceable food & Han and Qiao (2009) & \\
\hline $\begin{array}{l}\text { 10. Full understanding of food traceability from } \\
\text { consumers }\end{array}$ & & $\mathrm{X}$ \\
\hline $\begin{array}{l}\text { 11. Continuous support from vendors for traceability } \\
\text { systems implementation }\end{array}$ & Chetcuti (2008) & \\
\hline $\begin{array}{l}\text { 12. Support for traceability systems implementation from } \\
\text { all functional departments in enterprises }\end{array}$ & Zhang et al. (2002) & \\
\hline 13. System operation and maintenance investment & CCSFA (2007) & \\
\hline $\begin{array}{l}\text { 14. Traceability systems implementation considered as } \\
\text { corporate strategy by top management }\end{array}$ & Lee and Kim (2007) & \\
\hline $\begin{array}{l}\text { 15. Clear objectives for traceability systems } \\
\text { implementation }\end{array}$ & $\begin{array}{l}\text { (Doom et al. (2010); Nah } \\
\text { and Delgado (2006)) }\end{array}$ & \\
\hline $\begin{array}{l}\text { 16. Top management involvement in traceability systems } \\
\text { implementation }\end{array}$ & $\begin{array}{l}\text { (Lee and Kim (2007); Ngai } \\
\text { et al. (2004)) }\end{array}$ & \\
\hline $\begin{array}{l}\text { 17. Specific and rigorous arrangements for traceability } \\
\text { systems implementation }\end{array}$ & Nah and Delgado (2006) & \\
\hline $\begin{array}{l}\text { 18. Traceability systems operation strictly according to } \\
\text { schedule }\end{array}$ & Nah and Delgado (2006) & \\
\hline 19. Troubleshooting on time & Nah and Delgado (2006) & \\
\hline 20. Responsible administrators & Doom et al. (2010) & \\
\hline 21. Education and training for employees & Ngai et al. (2004) & \\
\hline 22. Trust between upstream and downstream companies & Ngai et al. (2004) & \\
\hline $\begin{array}{l}\text { 23. Timely communication between upstream and } \\
\text { downstream companies }\end{array}$ & Ngai et al. (2004) & \\
\hline $\begin{array}{l}\text { 24. Easy communication between upstream and } \\
\text { downstream companies }\end{array}$ & Ngai et al. (2004) & \\
\hline $\begin{array}{l}\text { 25. Sharing of information between upstream and } \\
\text { downstream companies }\end{array}$ & Ngai et al. (2004) & \\
\hline 26. The effectiveness of traceability information & & $\mathrm{X}$ \\
\hline 27. The integrity of traceability information & & $\mathrm{X}$ \\
\hline 28. The authenticity of traceability information & Xu et al. (2008) & \\
\hline 29. The standardization of traceability information & & $\mathrm{X}$ \\
\hline
\end{tabular}




\begin{tabular}{|l|l|l|}
\hline \multicolumn{1}{|c|}{ identification } & & \\
\hline 30. Excellent performance of traceability systems & Ngai et al. (2004) & \\
\hline 31. Satisfaction of users' need & Zhang and Wei (2009) & \\
\hline 32. Easy operation of traceability systems & DeLone and McLean (1992) & \\
\hline
\end{tabular}

\section{Table 6}

\section{Profile of Survey Respondents}

\begin{tabular}{lll}
\hline & Number & Percentage \\
\hline Position & 30 & \\
Manager & 13 & $10.5 \%$ \\
Project manager & 19 & $15.3 \%$ \\
Manager assistant & 19 & $15.3 \%$ \\
Technical expert & 22 & $17.7 \%$ \\
System implementation manager & 21 & $16.9 \%$ \\
System operator & 124 & 100.0 \\
\hline Total & & \\
\hline Implementation Experience & 14 & $11.3 \%$ \\
Under 2 years & 69 & $55.6 \%$ \\
2-3 years & 30 & $24.2 \%$ \\
4-6 years & 11 & $8.9 \%$ \\
over 6 years & $\mathbf{1 2 4}$ & $\mathbf{1 0 0 . 0}$ \\
\hline Total & & \\
\hline
\end{tabular}

\section{Table 7}

\section{Descriptive Statistics of Survey - Top 10 Individual Factors}

\begin{tabular}{|l|l|l|l|l|}
\hline Rank & Variable & Individual factors & Mean & Std. D \\
\hline 1 & V28 & The authenticity of traceability information & 4.50 & 0.770 \\
\hline 2 & V2 & Complete and adequate food traceability law & 4.43 & 0.808 \\
\hline 3 & V3 & $\begin{array}{l}\text { Complete and adequate food traceability } \\
\text { standards }\end{array}$ & 4.40 & 0.835 \\
\hline 4 & V15 & $\begin{array}{l}\text { Clear objectives for traceability systems } \\
\text { implementation }\end{array}$ & 4.22 & 0.822 \\
\hline 5 & V4 & $\begin{array}{l}\text { Policy guidance for enterprises' traceability } \\
\text { systems implementation from government }\end{array}$ & 4.20 & 0.796 \\
\hline 6 & V31 & $\begin{array}{l}\text { The specific function of traceability systems } \\
\text { satisfying users' need }\end{array}$ & 4.19 & 0.820 \\
\hline 7 & V1 & $\begin{array}{l}\text { Complete and adequate food traceability } \\
\text { regulations }\end{array}$ & 4.18 & 0.902 \\
\hline 8 & V29 & $\begin{array}{l}\text { The standardization of traceability information } \\
\text { identification }\end{array}$ & 4.09 & 0.884 \\
\hline 9 & V14 & $\begin{array}{l}\text { Traceability systems implementation being } \\
\text { considered by the top management in the } \\
\text { corporate strategy }\end{array}$ & 4.08 & 0.916 \\
\hline 10 & V26 & The effectiveness of traceability information & 4.07 & 0.857 \\
\hline
\end{tabular}


Table 8

Survey Results of Final EFA

\begin{tabular}{|c|c|c|c|c|c|c|c|}
\hline CSF Variables & F1 & F 2 & F3 & F4 & F5 & F6 & Communality \\
\hline $\begin{array}{l}\text { V1 regulation } \\
\text { V2 law } \\
\text { V3 standards }\end{array}$ & $\begin{array}{l}.739 \\
.740 \\
.554\end{array}$ & & & & & & $\begin{array}{l}.697 \\
.734 \\
.688\end{array}$ \\
\hline $\begin{array}{l}\text { V6 government investment } \\
\text { V7 government support }\end{array}$ & & $\begin{array}{l}.674 \\
.840\end{array}$ & & & & & $\begin{array}{l}.685 \\
.808\end{array}$ \\
\hline $\begin{array}{l}\text { V8 publicity to consumers from } \\
\text { government } \\
\text { V9 consumers' willingness } \\
\text { V10 consumers understanding }\end{array}$ & & & $\begin{array}{l}.730 \\
.806 \\
.576\end{array}$ & & & & $\begin{array}{l}.717 \\
.732 \\
.693 \\
\end{array}$ \\
\hline $\begin{array}{l}\text { V11vendor support } \\
\text { V12 internal support } \\
\text { V13 internal investment } \\
\text { V16 top management involvement } \\
\text { V18 traceability systems management }\end{array}$ & & & & $\begin{array}{l}.684 \\
.737 \\
.663 \\
.601 \\
.528\end{array}$ & & & $\begin{array}{l}.614 \\
.628 \\
.716 \\
.603 \\
.720\end{array}$ \\
\hline $\begin{array}{l}\text { V19 problem solving speed } \\
\text { V20 administration } \\
\text { V21 education and training } \\
\text { V22 trust } \\
\text { V23 timely communications } \\
\text { V24 easy communications } \\
\text { V25 information sharing }\end{array}$ & & & & & $\begin{array}{l}.587 \\
.731 \\
.589 \\
.556 \\
.751 \\
.814 \\
.672\end{array}$ & & $\begin{array}{l}.765 \\
.731 \\
.645 \\
.656 \\
.804 \\
.827 \\
.597\end{array}$ \\
\hline $\begin{array}{l}\text { V26 information effectiveness } \\
\text { V27 information integrity } \\
\text { V28 information authenticity } \\
\text { V29 information standardization } \\
\text { V30 traceability systems performance } \\
\text { V31 traceability systems functions } \\
\text { V32 traceability systems operation }\end{array}$ & & & & & & $\begin{array}{l}.808 \\
.710 \\
.659 \\
.734 \\
.558 \\
.602 \\
.635\end{array}$ & $\begin{array}{l}.841 \\
.797 \\
.769 \\
.679 \\
.715 \\
.598 \\
.608 \\
\end{array}$ \\
\hline $\begin{array}{l}\text { variance explained (\%) } \\
\text { Cumulative variance explained (\%) }\end{array}$ & $\begin{array}{l}8.07 \\
8.07 \\
\end{array}$ & $\begin{array}{ll}7.39 \\
15.46 \\
\end{array}$ & $\begin{array}{l}10.87 \\
26.33\end{array}$ & $\begin{array}{ll}12.71 \\
39.04 \\
\end{array}$ & $\begin{array}{l}15.66 \\
54.70 \\
\end{array}$ & $\begin{array}{l}21.92 \\
70.62 \\
\end{array}$ & \\
\hline
\end{tabular}


Table 9

Six dimensions of CSF identified in the study

\begin{tabular}{|ll|l|l|l|}
\hline \multicolumn{2}{|c|}{ Dimensions of Critical Success Factors } & $\begin{array}{l}\text { Unique to } \\
\text { traceability } \\
\text { systems }\end{array}$ & $\begin{array}{l}\text { Specifically } \\
\text { important to } \\
\text { China }\end{array}$ & $\begin{array}{l}\text { New to } \\
\text { existing } \\
\text { literature }\end{array}$ \\
\hline 1. & Laws, regulations and standards & Yes & Yes & No \\
\hline 2. & Government support & Yes & Yes & $\begin{array}{l}\text { Partially } \\
\text { (new CSF } \\
\text { identified) }\end{array}$ \\
\hline 3. & Consumer knowledge and support & Yes & Yes & $\begin{array}{l}\text { Partially } \\
\text { (new CSF } \\
\text { identified) }\end{array}$ \\
\hline 4. & $\begin{array}{l}\text { Top management, company-wide and vendor } \\
\text { support }\end{array}$ & No & No & No \\
\hline 5. & Effective management and communication & No & No & No \\
\hline 6. & Information quality and system quality & No & Yes & $\begin{array}{l}\text { Partially } \\
\text { (new CSF } \\
\text { identified) }\end{array}$ \\
\hline
\end{tabular}




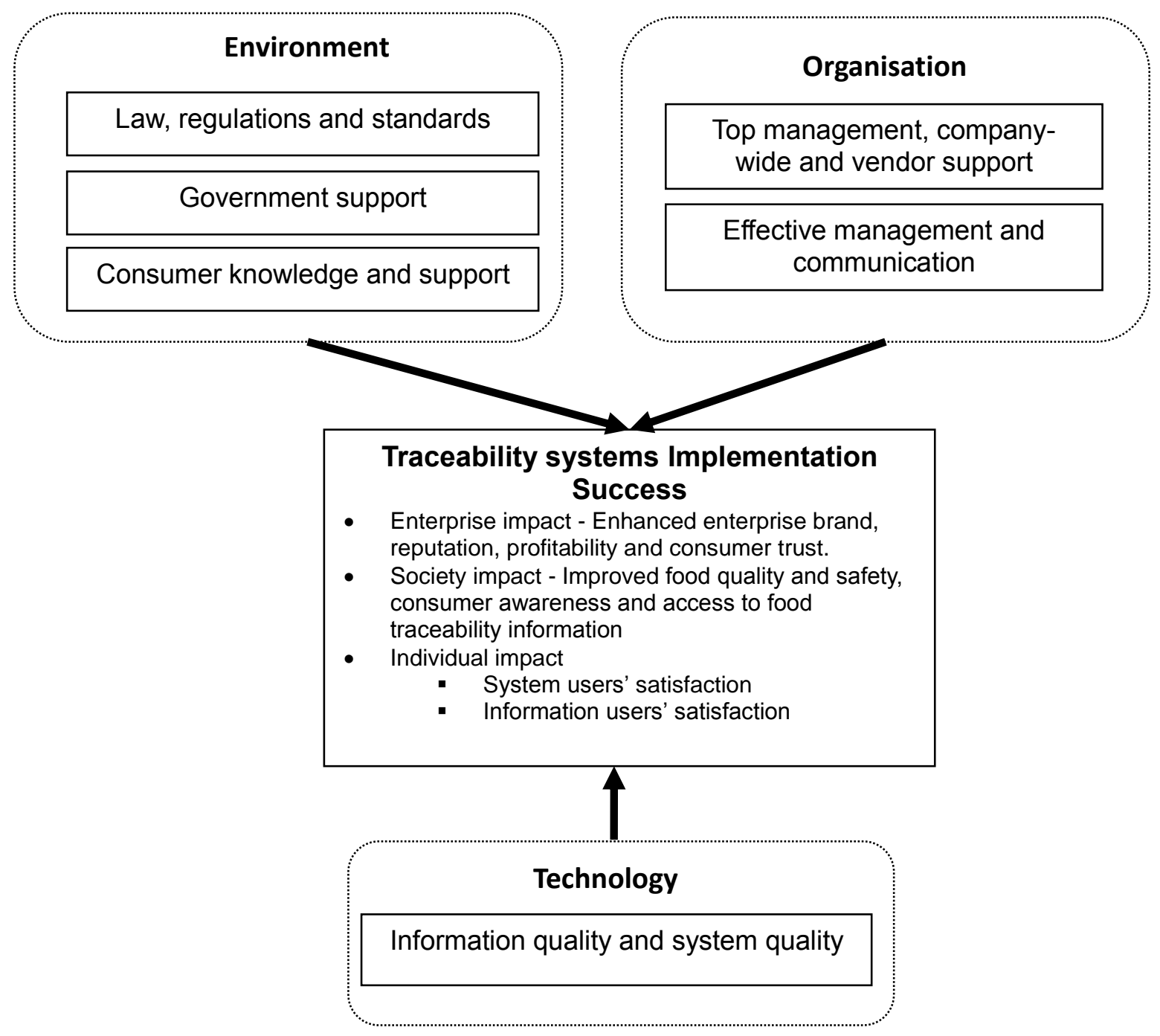

FIG. 1. A framework of critical success factors for food traceability systems implementation in China 
Appendix 1 - A summary of critical success factors adapted from literature

\begin{tabular}{|c|c|}
\hline Factors Affecting Traceability Systems Implementation & Supporting literature \\
\hline 1. Complete and adequate food traceability regulations & $\begin{array}{l}\text { Thakur and Hurburgh } \\
\text { (2009) }\end{array}$ \\
\hline 2. Complete and adequate food traceability laws & $\begin{array}{l}\text { Thakur and Hurburgh } \\
\text { (2009) }\end{array}$ \\
\hline 3. Complete and adequate food traceability standards & $\begin{array}{l}\text { Thakur and Hurburgh } \\
\text { (2009); Roth et al. (2008) }\end{array}$ \\
\hline $\begin{array}{l}\text { 4. Policy guidance for enterprises' traceability systems } \\
\text { implementation from government }\end{array}$ & Jiang (2007) \\
\hline $\begin{array}{l}\text { 5. Funding for traceability systems implementation from } \\
\text { government }\end{array}$ & Jiang (2007) \\
\hline $\begin{array}{l}\text { 6. Technology support for traceability systems implementation } \\
\text { from government }\end{array}$ & CCSFA (2007) \\
\hline 7. Food traceability publicity to consumers from the government & $\begin{array}{l}\text { (Jiang (2007); Xu and Wu } \\
(2008))\end{array}$ \\
\hline 8. Willingness to pay from consumers for traceable food & Han and Qiao (2009) \\
\hline $\begin{array}{l}\text { 9. Continuous support from vendors for traceability systems } \\
\text { implementation }\end{array}$ & Chetcuti (2008) \\
\hline $\begin{array}{l}\text { 10. Support for traceability systems implementation from all } \\
\text { functional departments in enterprises }\end{array}$ & Zhang et al. (2002) \\
\hline 11. System operation and maintenance investment & CCSFA (2007) \\
\hline $\begin{array}{l}\text { 12. Traceability systems implementation considered as corporate } \\
\text { strategy by top management }\end{array}$ & Lee and Kim (2007) \\
\hline 13. Clear objectives for traceability systems implementation & $\begin{array}{l}\text { (Doom et al. (2010); Nah } \\
\text { and Delgado (2006)) }\end{array}$ \\
\hline $\begin{array}{l}\text { 14. Top management involvement in traceability systems } \\
\text { implementation }\end{array}$ & $\begin{array}{l}\text { (Lee and Kim (2007); Ngai } \\
\text { et al. (2004)) }\end{array}$ \\
\hline $\begin{array}{l}\text { 15. Specific and rigorous arrangements for traceability systems } \\
\text { implementation }\end{array}$ & Nah and Delgado (2006) \\
\hline 16. Traceability systems operation strictly according to schedule & Nah and Delgado (2006) \\
\hline 17. Troubleshooting on time & Nah and Delgado (2006) \\
\hline 18. Responsible administrators & Doom et al. (2010) \\
\hline 19. Education and training for employees & Ngai et al. (2004) \\
\hline 20. Trust between upstream and downstream companies & Ngai et al. (2004) \\
\hline $\begin{array}{l}\text { 21. Timely communication between upstream and downstream } \\
\text { companies }\end{array}$ & Ngai et al. (2004) \\
\hline $\begin{array}{l}\text { 22. Easy communication between upstream and downstream } \\
\text { companies }\end{array}$ & Ngai et al. (2004) \\
\hline $\begin{array}{l}\text { 23. Sharing of information between upstream and downstream } \\
\text { companies }\end{array}$ & Ngai et al. (2004) \\
\hline 24. The authenticity of traceability information & Xu et al. (2008) \\
\hline 25. Excellent performance of traceability systems & Ngai et al. (2004) \\
\hline $\begin{array}{l}\text { 26. The specific function of traceability systems satisfying users' } \\
\text { need }\end{array}$ & Zhang and Wei (2009) \\
\hline 27. Easy operation of traceability systems & $\begin{array}{l}\text { DeLone and McLean } \\
(1992)\end{array}$ \\
\hline
\end{tabular}

